International Journal of Instruction e-ISSN: 1308-1470 • www.e-iji.net

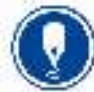

April 2021 • Vol.14, No.2

p-ISSN: 1694-609X

pp. $271-288$

Article submission code 20200218140349

Received: $18 / 02 / 2020$

Revision: 10/09/2020

Accepted: 04/10/2020

OnlineFirst: 21/01/202

\title{
Professional Readiness and Efficiency of Future Physical Education Teachers
}

\section{Tulegen Botagariev}

Department of Physical Culture and Sport, Aktobe Regional State University named after K. Zhubanov, Aktobe, Kazakhstan, botagarievtul@ rambler.ru

\section{Zura Khakimova}

Department of Physical Culture and Sport, Aktobe Regional State University named after K. Zhubanov, Aktobe, Kazakhstan, Zurka_82@mail.ru

\section{Joseph Andrushchishin}

Department of Theoretical Foundations of Physical Culture and Sports, Kazakh Academy of Sports and Tourism, Almaty, Kazakhstan, ifandru2@mail.ru

\section{Aiymgul Akhmetova}

Department of Mathematics, Aktobe Regional State University named after K. Zhubanov, Aktobe, Kazakhstan, aaimgul@ list.ru

\section{Saniay Konisbaeva}

Departament of Foreign Languages, Caspian State Technological and Engineering University named after Sh. Esenov, Aktau, Kazakhstan, konisbaeva_s@mail.ru

At the present stage of education development, the requirements for professional training of future specialists are increasing. The purpose of this study is to determine the efficiency of the developed experimental program for the formation of professional readiness of future physical education teachers. Using the methods of mathematical statistics, a comparative analysis has been carried out of the efficiency of the developed program for assessing the professional readiness of physical education teachers. The study involved 49 future teachers of physical education. Also the experimental group was trained using an innovative training program developed by the authors. The sample size was determined by the standard size of the study group at Kazakhstan universities and the participants of both groups were volunteers from the stream of the 2nd year of study at one of the Kazakhstan universities. According to the results of the training, a survey was conducted, the results of which were subjected to mathematical analysis. According to the intellectual and creative component - a relatively average level is revealed of all antonymic pairs, except responsible-irresponsible.

Keywords: development efficiency, experimental program, future teachers, physical education, professional readiness

Citation: Botagariev, T., Khakimova, Z. Andrushchishin, J. Akhmetova, A., \& Konisbaeva, S. (2021). Professional Readiness and Efficiency of Future Physical Education Teachers. International Journal of Instruction, 14(2), 271-288. https://doi.org/10.29333/iji.2021.14216a 


\section{INTRODUCTION}

Now in most countries of the world physical education, a healthy lifestyle and sports are a national idea that is taught to children from school throughout the entire period of their studies. According to OECD countries, the most common approach in physical education curricula in the development of basic motor skills $(100 \%)$, followed by physical well-being and health (94\%), sports (78\%), and games (72\%) and development of physical endurance (67\%) (OECD, 2019). Therefore, the physical education of the younger generation is an important area of education. The success of this undertaking largely depends on the professional readiness and competencies of the physical education teacher.

Studies in the field of professional readiness of physical education teachers have recently focused on the introduction of three groups of innovations into school education. First of all, this is medical knowledge, data from psychophysiology and biomechanics, sports medicine (Backman \& Larsson, 2016; Braga, Jones, Bulger \& Elliott, 2017; Quennerstedt, 2019). The second group of studies is related to the use of electronic education and components of electronic and multimedia technologies in the field of school education, in particular, in the field of sports training (Yang, 2018; Bakhmat al., 2019; Zhang, 2019). The third group of studies was devoted to the problem of inclusion and the problems of physical training, taking into account the characteristics of inclusive education (Fernandes, da Costa Filho \& Iaochite, 2019).

Technologies that are used in teaching attracted much attention, in particular, the possibility of using mobile applications and multimedia programs to provide educational information, using "cloud services" to study the results of students' training. Also, great attention is drawn to the possibility of using mobile applications and devices for remote monitoring and monitoring the health status of trainees (Webster et al., 2016). These are critical aspects of school preparation that integrate physical fitness into a modern digital environment.

Separate programs and teaching methods are also deeply investigated. In particular, the use of modern fitness programs for schooling, which naturally integrates classes at school with training outside the school (Cooper, 2016; Gryban et al., 2019; Jones, 2019). Also, the features of constructing programs for classes taking into account physical limitations or low preparedness of students leading a predominantly unhealthy lifestyle (Webster et al., 2016; Jones, 2019) are widely studied. However, the problem of preparing physical education teachers for the introduction of all these innovative methods in preparing students is poorly understood. The problem of the need to increase the willingness of teachers with regard to the introduction of e-education or STEM programs is considered very deeply in modern literature (Gryban et al., 2019). At the same time, it is assumed that for a physical education teacher, his own physical readiness and general methodological knowledge are sufficient. As is clear from the above, modern society poses ever higher challenges to physical education. Therefore, our study is designed to close the gap in the issue of improving the readiness and efficiency of teachers of physical education. First, in our training program we 
emphasized the willingness to perceive and introduce innovative technologies into educational practice.

The subject of physical education is an important component of the country's curriculum aimed at raising healthy and energetic young people with an emphasis on the psychomotor, cognitive, affective and physical form. However, the school and other organizations still do not pay due attention to the implementation of the subject of physical education (Mustafa \& Salleh, 2018). Strong motivation and attitude to pedagogical experience will help future teachers (who are the basis of the educational process) to work effectively that will be associated with pedagogical success (Francesco et al., 2019).

The requirements of the state standard of the Republic of Kazakhstan (Ministry of Education and Science of the Republic of Kazakhstan, 2017) provide for the formation of key competencies that characterize a modern specialist. To implement such tasks, the active introduction of innovative technologies in the educational process is necessary. The directions for improving the professional readiness of physical education teachers based on innovative technologies are relatively updated. The results of mathematical calculations are presented that justify the effectiveness of the developed experimental program.

Purpose of the study - determine the efficiency of the developed experimental program for the formation of professional readiness of future physical education teachers based on the application of mathematical statistics methods.

\section{LITERATURE REVIEW}

In the research literature on physical education, relatively little attention is paid to the importance of training teachers throughout their careers so that they could effectively train students in the field of physical education and be more concerned about their professional growth (Armour \& Yelling, 2007; Lee et al., 2017). An important social determinant of children's health and well-being is the social construction and creation of an educational system of physical education (Lawson, 2019). Namely, a system that includes social principles, program development, a knowledge base for rules and practice, as well as professional socialization for teachers, trainers and other leaders of physical education (Lawson, 2019).

The process of developing pedagogical skills of future physical education teachers in higher educational institutions is determined by the following (Maksymchuk et al., 2019; Maksymchuk et al., 2019). Kazakh researchers emphasize that the following aspects of the problem should be investigated in particular: criteria of motivational readiness (understanding the goals of the activity, awareness of the values of knowledge); theoretical readiness (applying knowledge of pedagogical activity); practical readiness (the use of knowledge and skills to solve problems. An indicator of the willingness of future teachers to innovative educational activities is the level of formation of this type of activity - adaptive, productive and creative. The formation of readiness for innovative activities in the school includes orienting, informational, modeling and integrating stages. Personally-oriented technology for the formation of 
professional competence includes a set of forms and methods of organizing the educational process. A competency model is also proposed with motivational, personal, cognitive and operational components. According to some authors, the educational process should dominate quasi-professional and educational-professional forms of activity; intensification and individualization; use of software training tools (Lobachev, 2007; Syunina et al., 2018; Maksymchuk et al., 2019).

Studies show the importance of blended learning, including automation and digitalization of processes where the attitude, knowledge, and skills of students are represented in proportion (Filenko et al., 2018; Turlacu et al., 2019). An innovative learning model is needed to meet the requirements of a future career and helps to build a dynamic, high-quality educational system (Zhang, 2019). Many authors emphasize the importance of information multimedia and virtual reality technologies for teaching various sports and physical training (Jenny et al., 2017; Yang, 2018). The positive effect of their use for teaching students is emphasized (Lubis et al., 2018). Even video games provide constant feedback with students and help motivate them, replace a sedentary lifestyle with an active game, and can contribute to social interaction (Tang, 2017).

Gawrisch et al. (2019) suggest a four-stage approach to teachers' preliminary education; accumulate knowledge, use modeling, experiment and collaborate with mentors, create and implement innovations. Other authors offer their options for the breakdown of the stages of the learning process (Pei \& Yang, 2019). Several works are devoted to what kind of emotional and motivational content a teacher of physical education should invest in the learning process (Alves et al., 2019; Reina et al., 2019; Alcala et al., 2019)

\section{METHOD}

\section{Research Design and Sample}

The study has been conducted based on K. Zhubanov Aktobe Regional State University. 49 young men took part in the study ( 25 people - experimental, 24 people - control group). The participants of both groups were volunteers from the stream of the 2 nd year of study at one of the Kazakhstan universities (from 228 students). Participants in the experimental group for one semester underwent training under the experimental program, the study of the results of which is the purpose of this study. The control group continued training on existing and approved training programs.

The participants of the control and experimental groups were at the initial stage of training and actually did not have prior professional sports or pedagogical experience, which ensured the purity of the experimental conditions. The choice of participants was based on averaged indicators among the population by age, level of training, and sports conditions. Gender differences were not considered significant for the purposes of this study. The survey was conducted voluntarily. Ethical issues related to the study have been reviewed and agreed upon by the ethics committee. The interview was organized by one researcher who had no relations with the participants. All participants were warned that their answers would be kept strictly confidential and used for academic purposes only. 


\section{Experiments}

At the first stage (January-February 2019), a research and experimental design scheme were prepared. In the second stage (February-May 2019), a stating experiment was conducted to determine the initial level of professional readiness of future physical education teachers. In parallel, a mathematical apparatus was developed that made it possible to substantiate the reliability of the used experimental program.

To determine the initial level of formation of the motivational-value component, the following methods were used. In the motivational-value component, the authors have identified such an indicator as "the intention to use innovative technologies in future professional activities." For this, the authors used a questionnaire survey (Gorshkov \& Sherega, 1985).

To identify the initial level of formation of the intellectual and creative component, the methodology for assessing the ability to make creative responsible decisions was applied (Andreev, 2006). The authors ascertain antonymic pairs and the alleged types of their manifestation: very high, high, above average, medium. Two elements were taken as a basis: the degree of specification of tasks and the degree of conformity and sophistication of the curriculum.

At this stage, the experimental program itself was developed and a stating experiment was conducted to identify the initial level of its components. Among them, a motivational and value component, intellectual and creative component, operational and technical component were identified. The experimental program includes approaches to analysis and assessment of the impact of these components on the formation of professional readiness of future physical education teachers.

\section{Data Collection Tools}

To determine the effectiveness of the implementation of the motivational-value component, a criterion was used, which was calculated by the following formula:

$x^{2}=\frac{1}{n_{g} n_{k}} \sum_{i=1}^{c} \frac{\left(n_{R} K_{i}-n_{K} E_{i}\right)^{2}}{E_{i}+K_{i}}=\frac{1}{n_{q} n_{K}} \frac{\left(n_{R} K_{1}-n_{K} E_{1}\right)^{2}}{E_{1}+K_{1}}+\frac{\left(n_{R} K_{2}-n_{K} E_{2}\right)^{2}}{E_{2}+K_{2}}+\frac{\left(n_{R} K_{3}-n_{K} E_{3}\right)^{2}}{E_{3}+K_{3}} \quad$ (Reina et al., 2019)

Where $n_{e}$ - the sum of the answers of experimental group participants, who have answered the questions "yes", "no", "I do not know".

$\mathrm{N}_{\mathrm{k}}$ - the sum of answers of control group participants, who have answered the questions "yes", "no", "I do not know".

$\mathrm{E}_{\mathrm{i}}$ - the number of experimental group's answers

$\mathrm{K}_{\mathrm{i}}$ - the number of control group's answers

White's criterion was used to determine the effectiveness of introducing the intellectual and creative components. The sequence of calculations is presented in the subsection "Research results". 
To determine the effectiveness of the implementation, an association coefficient was used. It was calculated by the following formula:

$$
\mathrm{ra}=\frac{\mathrm{ar}-\mathrm{bc}}{\sqrt{(\mathrm{a}+\mathrm{b})(\mathrm{c}+\mathrm{d})(\mathrm{a}+\mathrm{c})(\mathrm{b}+\mathrm{d})}}
$$

(2)

where $\mathrm{a}, \mathrm{b}, \mathrm{c}, \mathrm{d}-$ the number of alternative signs located in the cells of the correlation table (Zheleznyak \& Petrov, 2002).

Significance for all statistical tests was set at $\mathrm{p}=0.95$. The Student $\mathrm{t}$-test was used to assess differences in the mean values in the two samples.

\section{Research limitations}

The data presented in this article are consistent with the conducted analysis, although there are some limitations should be taken into account in future studies to obtain more generalized results and conclusions. Research has been conducted based on $\mathrm{K}$. Zhubanov Aktobe Regional State University, where the authors have received approval and permission to conduct observation and interrogation.

According to the motivational-value component, relatively low indicators are revealed of intention to use innovative technologies in future professional activities. According to the intellectual and creative component - a relatively average level of all antonymic pairs, except for "responsible-irresponsible". On operational-technical - a relatively negative degree of compliance and sophistication of training programs.

\section{FINDINGS}

The following Tables 1, 2 and 3 present the results of a study indicators of the key components of the effectiveness of future physical education teachers. This indicator of key components is necessary for the subsequent decision on whether research hypotheses have been confirmed or refuted.

Table 1 presents motivational component indicators of the professional readiness of future physical education teachers. As can be seen from Table 1, in the control group, compared with the experimental group, there are relatively fewer "yes" and "I do not know" answers concerning the intention to use innovative technologies in future professional activities.

Table 1

Motivational component indicators of professional readiness of future physical education teachers in terms of innovative technologies

\begin{tabular}{|c|c|c|c|}
\hline \multirow[t]{2}{*}{ Groups } & \multicolumn{3}{|c|}{$\begin{array}{l}\text { Do you intend to apply innovative technologies in future professional } \\
\text { activities? }\end{array}$} \\
\hline & Yes & No & I do not know \\
\hline Experimental & 78 & 15 & 7 \\
\hline Control & 60 & 22 & 18 \\
\hline
\end{tabular}


Table 2 presents the indicators for the test “assessment of students' ability to make creative responsible decisions".

Table 2

Indicators for the test "assessment of students' ability to make creative responsible decisions"

\begin{tabular}{|c|c|c|c|c|c|c|c|c|c|c|}
\hline \multirow[t]{2}{*}{ No. } & \multirow[t]{2}{*}{$\begin{array}{l}\text { Antonymic } \\
\text { pairs }\end{array}$} & \multicolumn{3}{|c|}{$\begin{array}{l}\text { Experimental } \\
\text { Group, } n=24\end{array}$} & \multicolumn{3}{|c|}{ Control group, $n=25$} & \multirow[t]{2}{*}{ Growth } & \multirow[t]{2}{*}{$\begin{array}{l}\text { Student } \\
\text { t-test }\end{array}$} & \multirow[t]{2}{*}{$\mathrm{P}$} \\
\hline & & $\bar{X}$ & $\mathrm{~S}$ & $\mathrm{~m}$ & $\bar{X}$ & $\mathrm{~S}$ & $\mathrm{~m}$ & & & \\
\hline 1 & $\begin{array}{l}\text { Decisive- } \\
\text { indecisive }\end{array}$ & 13.5 & 0.23 & 0.06 & 13.9 & 0.15 & 0.04 & 1.4 & 4.28 & $<0.01$ \\
\hline 2 & $\begin{array}{l}\text { Responsible- } \\
\text { irresponsible }\end{array}$ & 11.5 & 0.24 & 0.06 & 12.0 & 0.21 & 0.05 & 4.3 & 6.25 & $<0.01$ \\
\hline 3 & $\begin{array}{l}\text { Strategist- } \\
\text { tactician }\end{array}$ & 13.0 & 0.21 & 0.05 & 13.2 & 0.23 & 0.06 & 1.5 & 3.8 & $<0.05$ \\
\hline 4 & $\begin{array}{l}\text { Intuitive- } \\
\text { logician }\end{array}$ & 13.2 & 0.22 & 0.05 & 13.5 & 0.24 & 0.06 & 3.0 & 5 & $<0.01$ \\
\hline 5 & $\begin{array}{l}\text { Creative- } \\
\text { conservative }\end{array}$ & 13.1 & 0.23 & 0.05 & 13.6 & 0.19 & 0.06 & 2.2 & 6.25 & $<0.01$ \\
\hline
\end{tabular}

Table 2 shows the following tendency for antonymic pairs. Except for the "responsibleirresponsible" pair, all other pairs have an average level. The marked pair has an aboveaverage level. It should be noted that in the control group for all pairs, a relative excess of indicators' values compared with the experimental group is noted. Statistically significant differences are revealed between the values of the studied pairs in the control and experimental groups $(\mathrm{p}<0.01)$.

Table 3 presents some indicators of the operational-technical component of the professional readiness of future physical education teachers.

Table 3

Operational-technical component indicators of professional readiness of future physical education teachers

\begin{tabular}{llll}
\hline No. & Feature & Present (positive) & Absent (negative) \\
\hline 1 & $\begin{array}{l}\text { The degree of specification and } \\
\text { compliance with goals and objectives }\end{array}$ & $\mathrm{a}=23$ & $\mathrm{~b}=2$ \\
\hline 2 & $\begin{array}{l}\text { The degree of conformity and } \\
\text { sophistication of training programs }\end{array}$ & $\mathrm{c}=17$ & $\mathrm{~d}=8$ \\
\hline
\end{tabular}

\section{The first working hypothesis}

It is assumed that the experimental program will be more effective if implemented in an experimental group rather than the control group. Besides, the experimental group's students are more likely to give positive answers to the question "Do you intend to use innovative technologies?" Table 4 presents the calculated indicators for the chi-square. 
Table 4

The motivational component of professional readiness of future physical education teachers

\begin{tabular}{|c|c|c|c|c|c|}
\hline \multirow[t]{2}{*}{ Groups } & \multicolumn{2}{|c|}{$\begin{array}{l}\text { Do you intend to apply innovative technologies in } \\
\text { future professional activities? }\end{array}$} & \multirow[t]{2}{*}{$\mathrm{X}_{\mathrm{e}}^{2}$} & \multirow[t]{2}{*}{$\mathrm{X}_{\mathrm{k}}^{2}$} & \multirow[t]{2}{*}{$\mathrm{P}$} \\
\hline & Yes $\quad$ No & I do not know & & & \\
\hline Experimental & 15 & 7 & 8.51 & 6.0 & 0.05 \\
\hline Control & 60 & 18 & & & \\
\hline
\end{tabular}

$\mathrm{H}_{1}$ : The experimental program implemented in the experimental group is more effective, and in this group, there are more positive answers to the question "Do you intend to apply innovative technologies in future professional activities?" than in the control group. Hypothesis $\mathrm{H}_{1}$ is accepted.

\section{Second working hypothesis}

$\mathrm{H}_{1}$ : the experimental program implemented in the experimental group will be more effective, and the students of this group will have higher results for such antonymic pairs as decisive-indecisive, responsible-irresponsible, strategist-tactician, intuitive-logician, creative-conservative than control group students. For each antonymic pair, a hypothesis was developed separately and calculations were made (Table 5).

Table 5

The scores obtained by each of the subjects of the control and experimental groups in the block "decisive-indecisive"

\begin{tabular}{llllll}
\hline No. & $\begin{array}{l}\text { Experimental } \\
\text { group }\end{array}$ & Scores of E.g. $\boldsymbol{R}_{\boldsymbol{e}}$ & No. & Control group & Scores of C.g. $R_{\boldsymbol{k}}$ \\
\hline 1 & 10.5 & 7 & 1 & 13.0 & 17 \\
\hline 2 & 11.0 & 13.5 & 2 & 13.2 & 19.5 \\
\hline 3 & 11.5 & 15 & 3 & 13.3 & 21.5 \\
\hline 4 & 10.6 & 8 & 4 & 13.8 & 29 \\
\hline 5 & 10.9 & 11.5 & 5 & 13.8 & 29 \\
\hline 6 & 10.8 & 10 & 6 & 13.7 & 27 \\
\hline 7 & 10.4 & 6 & 7 & 13.6 & 26 \\
\hline 8 & 10.9 & 11.5 & 8 & 13.8 & 29 \\
\hline 9 & 11.0 & 13.5 & 9 & 13.3 & 21.5 \\
\hline 10 & 10.7 & 9 & 10 & 13.4 & 23.5 \\
\hline 11 & 10.3 & 4 & 11 & 13.5 & 25 \\
\hline 12 & 11.9 & 16 & 12 & 13.2 & 19.5 \\
\hline 13 & 10.1 & 1 & 13 & 13.1 & 18 \\
\hline 14 & 10.2 & 2 & 14 & 13.4 & 23.5 \\
\hline 15 & 10.3 & 4 & & & \\
\hline 16 & 10.3 & 4 & & Sum & 329 \\
\hline
\end{tabular}

$\mathrm{H}_{1}$ : the experimental program implemented in the experimental group will turn out to be more effective, and the students of this group for an antonymic pair "decisiveindecisive" will have higher results than control group students. 
The coincidence of the calculated sum of the ranks and the empirically calculated ones shows that all the data are correctly ranged. According to the table of critical values for:

$n_{1}=16 ; n_{2}=14 ; T_{c r}=169$ at $\mathrm{p}=0.95$

Let us compare the smaller sum of the empirically calculated two sums with the critical value: $136<169, \mathrm{H}_{1}$ hypothesis applies (Table 6).

Table 6

The received scores by each of the subjects of the control and experimental groups in the block "responsible-irresponsible"

\begin{tabular}{llllll}
\hline No. & Experimental group & Scores of E.g. $R_{\boldsymbol{e}}$ & No. $\begin{array}{l}\text { Control } \\
\text { group }\end{array}$ & Scores of C.g. $R_{k}$ \\
\hline 1 & 9.0 & 1 & 1 & 13.0 & 17 \\
\hline 2 & 9.2 & 2.5 & 2 & 13.2 & 19 \\
\hline 3 & 9.8 & 8 & 3 & 13.4 & 20.5 \\
\hline 4 & 9.5 & 5 & 4 & 13.5 & 22 \\
\hline 5 & 10.1 & 9 & 5 & 13.1 & 18 \\
\hline 6 & 10.5 & 13 & 6 & 13.6 & 23.5 \\
\hline 7 & 10.6 & 14 & 7 & 13.7 & 25.5 \\
\hline 8 & 10.9 & 16 & 8 & 13.8 & 27.5 \\
\hline 9 & 9.7 & 7 & 9 & 13.9 & 29.5 \\
\hline 10 & 10.4 & 11.5 & 10 & 13.6 & 23.5 \\
\hline 11 & 10.8 & 15 & 11 & 13.4 & 20.5 \\
\hline 12 & 10.4 & 11.5 & 12 & 13.7 & 25.5 \\
\hline 13 & 10.3 & 10 & 13 & 13.8 & 27.5 \\
\hline 14 & 9.6 & 6 & 14 & 13.9 & 29.5 \\
\hline 15 & 9.3 & 4 & & & \\
\hline 16 & 9.2 & 2.5 & & & \\
\hline \multicolumn{7}{l}{ Sum } & 136 & & & \\
\hline
\end{tabular}

$\mathrm{H}_{1}$ : the experimental program implemented in the experimental group will be more effective, and the students of this group will have higher results for an antonymic pair "responsible-irresponsible" than control group students.

The coincidence of the calculated sum of the ranks and the empirically calculated ones shows that all the data are ranked correctly.

According to the table of critical values for:

$n_{1}=16 ; n_{2}=14 ; T_{c r}=169$ at $\mathrm{p}=0.95$

Let us compare the smaller sum of the empirically calculated two sums with the critical value: $136<169, \mathrm{H}_{1}$ hypothesis applies (Table 7). 
Table 7

The scores obtained by each of the subjects of the control and experimental groups in the block "strategist-tactician"

\begin{tabular}{llllll}
\hline $\begin{array}{l}\text { No } \\
\cdot\end{array}$ & $\begin{array}{l}\text { Experimental } \\
\text { group }\end{array}$ & Scores of E.g. $\boldsymbol{R}_{\boldsymbol{e}}$ & No. & Control group & Scores of C.g. $\boldsymbol{R}_{\mathbb{R}}$ \\
\hline 1 & 10.5 & 4 & 1 & 13.0 & 17 \\
\hline 2 & 11.0 & 8 & 2 & 13.1 & 18 \\
\hline 3 & 10.1 & 1 & 3 & 13.2 & 19 \\
\hline 4 & 10.3 & 2.5 & 4 & 13.4 & 22 \\
\hline 5 & 10.8 & 6 & 5 & 13.4 & 22 \\
\hline 6 & 10.9 & 7 & 6 & 13.5 & 24.5 \\
\hline 7 & 10.6 & 5 & 7 & 13.6 & 26 \\
\hline 8 & 11.3 & 9 & 8 & 13.7 & 27.5 \\
\hline 9 & 11.4 & 10 & 9 & 13.8 & 29 \\
\hline 10 & 11.5 & 11 & 10 & 13.3 & 20 \\
\hline 11 & 11.6 & 12.5 & 11 & 13.4 & 22 \\
\hline 12 & 11.7 & 14 & 12 & 13.5 & 24.5 \\
\hline 13 & 11.8 & 15 & 13 & 13.9 & 30 \\
\hline 14 & 11.9 & 16 & 14 & 13.7 & 27.5 \\
\hline 15 & 11.6 & 12.5 & & & \\
\hline 16 & 10.3 & 2.5 & & & 329 \\
\hline & Sum & 136 & & Sum & \\
\hline
\end{tabular}

$\mathrm{H}_{1}$ : the experimental program implemented in the experimental group will be more effective, and the students of this group will have higher results for an antonymic pair "strategist-tactician" than control group students.

According to the table of critical values for $n_{1}=16 ; n_{2}=14 ; T_{c F}=169$ at $\mathrm{p}=0.95$

Let us compare the smaller sum of the empirically calculated two sums with the critical value: $136<169, \mathrm{H}_{1}$ hypothesis applies (Table 8 ). 
Table 8

The scores obtained by each of the subjects of the control and experimental groups in the block "intuitive-logician"

\begin{tabular}{llllll}
\hline No. & Experimental group & Scores of E.g. $\mathbb{R}_{\boldsymbol{e}}$ & No. & Control group & Scores of C.g. $\mathbb{R}_{\boldsymbol{k}}$ \\
\hline 1 & 11.0 & 1,5 & 1 & 13.0 & 17 \\
\hline 2 & 11.2 & 4 & 2 & 13.1 & 18 \\
\hline 3 & 11.3 & 5 & 3 & 13.2 & 20 \\
\hline 4 & 11.1 & 3 & 4 & 14.0 & 29.5 \\
\hline 5 & 11.4 & 6.5 & 5 & 14.0 & 29.5 \\
\hline 6 & 11.5 & 8.5 & 6 & 13.9 & 28 \\
\hline 7 & 11.6 & 10.5 & 7 & 13.8 & 27 \\
\hline 8 & 11.8 & 14 & 8 & 13.7 & 26 \\
\hline 9 & 11.9 & 16 & 9 & 13.6 & 25 \\
\hline 10 & 11.0 & 1.5 & 10 & 13.5 & 23 \\
\hline 11 & 11.7 & 12 & 11 & 13.4 & 22 \\
\hline 12 & 11.8 & 14 & 12 & 13.3 & 20 \\
\hline 13 & 11.4 & 6.5 & 13 & 13.2 & \\
\hline 14 & 11.5 & 8.5 & 14 & 13.2 & \\
\hline 15 & 11.6 & 10.5 & & & 329 \\
\hline 16 & 11.8 & 14 & & & Sum \\
\hline \multicolumn{7}{l}{ Sum } & 136 & & & \\
\hline
\end{tabular}

$\mathrm{H}_{1}$ : the experimental program implemented in the experimental group will be more effective, and the students of this group will have higher results for an antonymic pair "intuitive-logician" than control group students.

Let us compare the smaller sum of the empirically calculated two sums with the critical value: $136<169, \mathrm{H}_{1}$ hypothesis applies (Table 9).

Table 9

The scores obtained by each of the subjects of the control and experimental groups in the block "creative-conservative"

\begin{tabular}{|c|c|c|c|c|c|}
\hline No. & Experimental group & Scores of E.g. $R_{e}$ & No. & Control group & Scores of C.g. $\mathbb{R}_{\mathbb{R}}$ \\
\hline 1 & 10.1 & 1 & 1 & 13.0 & 17 \\
\hline 2 & 10.2 & 2 & 2 & 13.1 & 19 \\
\hline 3 & 10.3 & 3 & 3 & 13.2 & 21.5 \\
\hline 4 & 10.4 & 4 & 4 & 13.3 & 23 \\
\hline 5 & 10.5 & 5 & 5 & 13.1 & 19 \\
\hline 6 & 10.6 & 6 & 6 & 13.2 & 21.5 \\
\hline 7 & 10.8 & 7 & 7 & 13.4 & 24 \\
\hline 8 & 11.2 & 10 & 8 & 13.5 & 25 \\
\hline 9 & 11.3 & 11 & 9 & 13.6 & 26 \\
\hline 10 & 11.4 & 12 & 10 & 13.7 & 27 \\
\hline 11 & 11.5 & 13 & 11 & 13.8 & 28 \\
\hline 12 & 11.6 & 14 & 12 & 13.9 & 29 \\
\hline 13 & 11.7 & 15 & 13 & 14.0 & 30 \\
\hline 14 & 11.8 & 16 & 14 & 13.1 & 19 \\
\hline 15 & 10.9 & 8 & & & \\
\hline \multirow[t]{2}{*}{16} & 11.1 & 9 & & & \\
\hline & Sum & 136 & & Sum & 329 \\
\hline
\end{tabular}


$\mathrm{H}_{1}$ : the experimental program implemented in the experimental group will be more effective, and the students of this group will have higher results for an antonymic pair "creative-conservative" than control group students.

Let us compare the smaller sum of the empirically calculated two sums with the critical value: $136<169, \mathrm{H}_{1}$ hypothesis applies.

\section{The third working hypothesis}

Let us determine the relationship between the degree of specification, the correspondence of tasks and the degree of conformity and sophistication of the training programs in basketball.

$\mathrm{H}_{1}$ : There is a positive statistically significant relationship between the degree of specification, the correspondence of tasks and the degree of conformity and sophistication of basketball training programs.

For this, the authors calculate the coefficient of association $(\mathrm{ra})$.

To calculate the association coefficient, the authors compose a four-field correlation table (Table 10).

Table 10

Four-field correlation table

\begin{tabular}{lllll}
\hline No. & Feature & Present (positive) & Absent (negative) & Sum \\
\hline 1 & $\begin{array}{l}\text { The degree of specification and } \\
\text { compliance with goals and } \\
\text { objectives }\end{array}$ & $\mathrm{a}=23$ & $\mathrm{~b}=2$ & $\mathrm{a}+\mathrm{b}=25$ \\
\hline 2 & $\begin{array}{l}\text { The degree of conformity and } \\
\text { sophistication of training programs }\end{array}$ & $\mathrm{c}=17$ & $\mathrm{~d}=8$ & $\mathrm{c}+\mathrm{d}=25$ \\
\hline & Sum & $\mathrm{a}+\mathrm{c}=40$ & $\mathrm{~b}+\mathrm{d}=10$ & $\mathrm{~N}=50$ \\
\hline
\end{tabular}

where $\mathrm{a}, \mathrm{b}, \mathrm{c}, \mathrm{d}$ - the alternative features located in the cells of the correlation "table". The coefficient of association $r_{a}=0,3$ according to the formula (2). There is a positive correlation. Let us check the reliability of this coefficient. To do this, the authors calculate the following:

$r_{a} \sqrt{N-1}=0,3 \cdot \sqrt{50-1}=0,3 \cdot 7=2,1$.

According to the table "Values of the correlation coefficient at the significance level

$p=0.05$ and number of degrees of freedom $K=N-2$, the critical value of the association coefficient turned out to be $r_{G \in C}=0.28$. Let us calculate the following value:

$r_{C \mathrm{Cr}}=\sqrt{N-1}=0.28 \cdot \sqrt{50-1}=0.28 \cdot 7-1.96$ 
The calculation shows that $r_{a}=\sqrt{N-1}>r_{a \in C}=\sqrt{N-1} \quad(2.1>1.96)$. Consequently, the positive relationship found between the degree of specification, the correspondence of tasks and the degree of conformity and sophistication of the curriculum in basketball is considered reliable:

$r_{a}=0.136$ at $\mathrm{p}>0.05$

\section{DISCUSSION}

As can be seen from Table 3, 23 respondents have a positive degree of specification of compliance with goals and objectives; in 2 - negative. 17 students have a positive degree of conformity and sophistication of the training programs; 8 - negative. The authors have developed an experimental program for correcting the components of professional readiness formation in physical education teachers. Based on the conducted experiment, the authors have determined the following prerequisites for the development of the experimental program.

In the motivational-value component, the contradiction is the proportion of students who do not intend to apply innovative technologies in their future professional activities (Table 1 and 4). The authors see a way to resolve this contradiction in the development of the elective course "Formation of the professional readiness of future physical education teachers". The latter should provide the basic elements of the readiness of future physical education teachers, pedagogical conditions for its formation. In the intellectual-creative component, the contradiction is the relatively average level of all antonymic pairs, except for "responsible-irresponsible" (Table 6). The way to resolve this contradiction is to create problematic situations that require the manifestation of activities that increase the level of these antonymic pairs.

In the operational-technical component (Table 3), a contradiction is the relative presence of a negative degree of compliance and sophistication of training programs. Way to resolve this contradiction is to provide creative tasks with adequate content and the means and methods for solving them (Prontenko et al., 2019). To determine the effectiveness of an experimental program for the formation of professional readiness in physical education teachers, the authors have formulated working hypotheses, which have been tested using mathematical statistics methods.

The processes of changing traditional social values (Syunina et al, 2018) observed in modern society, have led to the urgent need for the educational system to contribute to spiritual and moral self-identification, personal growth of the younger generation. This circumstance determined increased the level of requirements for the professional and personal component of pedagogical activity. According to some authors (Prontenko et al., 2019), the main components of the readiness of future physical education teachers for professional activities are defined as active and motivational. However, as our study shows, the motivation for pedagogical work itself or the teacher's self-improvement does not correspond to the motivation for innovation (Table 1 and 4). This problem requires a separate solution in the form of independent training programs or components 
of such programs that form the corresponding motivation of the teacher. The activity component is the main component that contributes to the transformation of theoretical knowledge about physical education into practical skills. It is necessary to pay attention to job satisfaction, what issue is considered in the work of Kroupis et al. (2019).

For future physical education teachers, an important element of professional readiness is the ability to apply innovative approaches to teaching. An example of such an approach is given in Akhmetshin et al. (2019), which examines the effectiveness of using the fundamentals of football in physical education and the organization of artistic and cultural events to promote the harmonious development of orphans. In our study, the components associated with decision-making and the antonymic pairs "logical inductive" (Table 8) or "strategic-tactician" (Table 7) demonstrate those elements of thinking that provide future teachers with high activity and the use of creative elements similar to those described in this paper. Questions of professional readiness of physical education teachers in the context of the development of physical education and the art of teaching can also be found in Quennerstedt (2019). Improving the quality of the implementation of the creative component in the pedagogical process is most reflected in our study with the results in Table 9.

The teacher training components presented in Tables 5 and 6 are most related to interaction with students' personalities and the ability to make decisions and solve difficulties during the lesson, and not in connection with the teaching methodology. This aspect of the teacher's work is especially well studied in works on the problems of inclusion and interaction with students (Backman \& Larsson, 2016; Fernandes, da Costa Filho \& Iaochite, 2019; Jones, 2019).

Of some interest is the work of Mondaca-Fernandez (2019), which studies the technology for improving the learning environment in the framework of training physical education teachers. In contrast to the results of other studies, the current study indicates that in the control group, compared with the experimental group, there are relatively fewer "yes" and "I do not know" answers concerning the intention to use innovative technologies in future professional activities (60 and 18 vs. 78 and 7).

The following results were revealed for the antonymic activities of the experimental and control groups: decisive-indecisive (13.5 and 13.9); responsible-irresponsible (11.5 and 12.0); strategist-tactician (13.0 and 13.2); intuitive-logician (13.2 and 13.5); creativeconservative (13.1 and 13.6).

\section{CONCLUSIONS}

Thus, differences between the experimental and control groups at the level of $\mathrm{p}=0.95$ were found. That is, the influence of the motivational component of the professional readiness of future physical education teachers in the experimental group of students is higher than in the control group.Lower values of indicators of motivational, intellectualcreative and operational-technical components of professional readiness of future physical education teachers are determined. An experimental program has been developed for the formation of professional readiness for future physical education. Using the methods of mathematical statistics, it was found that in the control group, 
compared to the experimental group, there are relatively fewer answers "yes" and "I do not know" in the intention to use innovative technologies in the future professional activities (60 and 18 vs. 78 and 7).

The results of the study can be used in determining the level of professional readiness, developing ways to improve it and assessing its effectiveness in the world practice of training physical education specialists.

\section{REFERENCES}

Akhmetshin, E. M., Miftakhov, A. F., Murtazina, D. A., Sofronov, R. P., Solovieva, N. M., \& Blinov, V. A. (2019). Effectiveness of using football basics in physical education and organizing arts and cultural events for promoting harmonious development of orphan children. International Journal of Instruction, 12(1), 539-554.

Alcala, D. H., Rio, J. F., Calvo, G. G., \& Pueyo, A. P. (2019). Comparing effects of a TPSR training program on prospective physical education teachers' social goals, discipline and autonomy strategies in Spain, Chile and Costa Rica. Physical Education and Sport Pedagogy, 24(3), 220-232.

Alves, M., MacPhail, A., Queiros, P., \& Batista, P. (2019). Becoming a physical education teacher during formalised school placement: A rollercoaster of emotions. European Physical Education Review, 25(3), 893-909.

Andreev, V. I. (2006). Pedagogy: Training course for creative self-development. Kazan: Center for Innovative Technologies.

Armour, K. M., \& Yelling, M. (2007). Effective professional development for physical education teachers: The role of informal, collaborative learning. Journal of Teaching in Physical Education, 26(2), 177-200.

Backman, E., \& Larsson, H. (2016). What should a physical education teacher know? An analysis of learning outcomes for future physical education teachers in Sweden. Physical Education and Sport Pedagogy, 21(2), 185-200.

Bakhmat, N., Maksymchuk, B., Voloshyna, O., Kuzmenko, V., Matviichuuk, T., Kovalchuk, A., ... \& Shelan, M. (2019). Designing cloud-oriented university environment in teacher training of future physical education teachers.

Braga, L., Jones, E., Bulger, S., \& Elliott, E. (2017). Empowering teachers to implement innovative content in physical education through continuous professional development. Teacher Development, 21(2), 288-306.

Cooper, D. (2016). Teaching the Pedagogy of Games Play to Future Physical Education Teachers. Research Quarterly for Exercise and Sport, 87(S1), S88.

Fernandes, M. M., da Costa Filho, R. A., \& Iaochite, R. T. (2019). Teacher self-efficacy of future physical education teachers in contexts of inclusion in basic education. Revista Brasileira de Educacao Especial, 217-230. 
Filenko, L., Ashanin, V., Pasko, V., Tserkovna, O., Filenko, I., Dzhym, V., \& Tykhorskyi, O. (2018). Introduction of the physical game rugby-5 into the physical education of students by means of information technology. Research Journal of Pharmaceutical Biological and Chemical Sciences, 9(3), 1293-1302.

Francesco, C., Coco, D., Frattini, G., Vago, P., \& Andrea, C. (2019). Effective teaching competences in Physical Education. Journal of Physical Education and Sport, 19(5), 1806-1813.

Gawrisch, D. P., Richards, K. A. R., \& Killian, C. M. (2019). Integrating Technology in Physical Education Teacher Education: A Socialization Perspective. Quest, 1, 2-18.

Gorshkov, M. K., \& Sherega, F. (1985). How to conduct a sociological study. Moscow: Politizdat.

Gryban, G., Prontenko, K., Zhamardiy, V., Tkachenko, P., Kruk, M., Kostyuk, Y., \& Zhukovskyi, Y. (2018). Professional stages of a physical education teacher as determined using fitness technologies.

Jenny, S. E., Schary, D. P., Noble, K. M., \& Hamill, S. D. (2017). The effectiveness of developing motor skills through motion-based video gaming. Simulation \& Gaming, 48(6), $722-734$.

Jones, E. (2019). Recruitment of Future Physical Education Teachers Will Require All Hands on Deck.

Kroupis, I., Kouli, O., \& Kourtessis, T. (2019). Physical education teacher's job satisfaction and burnout levels in relation to school's sport facilities. International Journal of Instruction, 12(4), 579-592.

Lawson, H. A. (2019). The physical education system as a consequential social determinant. Quest, 72(1), 72-84.

Lee, O., Ravizza, D. M., Muller, S. M., \& Satern, M. N. (2017). Navigating academia: Developing a road map for a professional journey for physical education teacher candidates. Journal of Physical Education, Recreation \& Dance, 88(3), 29-35.

Lobachev, V. V. (2007). Pedagogical conditions for the formation of readiness of future physical education teachers for professional activities. Dissertation of the candidate of pedagogical sciences, Voronezh.

Lubis, M., Parsusah, M., Komaro, M., \& Djohar A. (2018). Blended learning, implementation strategy: The new era of education. In Proceedings of the 5th UPI International Conference on Technical and Vocational Education and Training (ICTVET 2018). Advances in Social Science Education and Humanities Research, Vol. 299, pp. 64-65.

Maksymchuk, I., Maksymchuk, B., Frytsiuk, V., Matviichuk, T., Demchenko, I., Babii, I., Tsymbal-Slatvinska, S., Nikitenko, A., Bilan, V., Sitovskyi, A., \& Savchuk, I. (2019). 
Formation of readiness of future physical culture teachers for professional activity. Universal Journal of Educational Research, 7(9), 1860-1868.

Ministry of Education and Science of the Republic of Kazakhstan (2017). On the features of organizing educational processes in secondary schools of the Republic of Kazakhstan in the academic year 2017-2018: Instructions and methodical letters. Astana: National Academy of Education named after I. Altynsarin.

Mondaca-Fernandez, F. (2019). Technology Enhanced Learning Environments within Physical Education Teacher Education: Application of Self-Regulated learning and Self-Determination Theory. Doctor of Philosophy thesis, School of Education, University of Wollongong.

Mustafa, M. A., \& Salleh, N. M. (2018). Sport education in primary school in Malaysia. International Journal of Academic Research in Business and Social Sciences, 8(12), 1723-1730.

OECD (2019). Making Physical Education Dynamic and Inclusive for 2030 International Curriculum Analysis. OECD Future of Education 2030. Retrieved 15 January, 2020 from https://www.oecd.org/education/2030project/contact/OECD_FUTURE_OF_EDUCATION_2030_MAKING_PHYSICAL_D YNAMIC_AND_INCLUSIVE_FOR_2030.pdf

Pei, M., \& Yang, H. Z. (2019). Developing teacher agency and self-regulation in a professional training program: a case study in a rural and ethnic minority area of China. Asia Pacific Education Review, 20(4), 625-639.

Prontenko, K., Bloshchynskyi, I., Griban, G., Zhukovskyi, Y., Yavorska, T., Tkachenko, P., Dzenzeliuk, D., Dovgan, N., Bezpaliy, S., \& Andreychuk, V. (2019). Formation of readiness of future physical culture teachers for professional activity. Universal Journal of Educational Research, 7(9), 1860-1868.

Prontenko, K., Bloshchynskyi, I., Gryban, G., Zhukovskyi, Y., Yavorska, T., Tkachenko, P., ... \& Andreychuk, V. (2019). Formation of readiness of future physical culture teachers for professional activity.

Quennerstedt, M. (2019) Physical education and the art of teaching: transformative learning and teaching in physical education and sports pedagogy. Sport, Education and Society, 24(6), 611-623.

Reina, R., Healy, S., Roldan, A., Hemmelmayr, I., \& Klavina, A. (2019). Incluye-T: a professional development program to increase the self-efficacy of physical educators towards inclusion. Physical Education and Sport Pedagogy, 24(4), 319-331.

Syunina, A., Yarmakeev, I., Valiakhmetova, N., Akhmadullina, R. \& Gibadullin, R. (2018). Formation of future teachers' readiness for professional and moral selfdevelopment. Journal of Interdisciplinary Research, 8(1), 153-156.

Tang, F. C. (2017). Reform strategies on universities physical education in the background of quality education. In Proceedings of the 2017 3rd International 
Conference on Economics, Social Science, Arts, Education and Management Engineering (ESSAEME 2017). Advances in Social Science Education and Humanities Research, Vol. 119, pp. 2144-2148.

Turlacu, L. M., Orzan, G., Chivu, R. G., \& Herrezeel, T. (2019). Strategic technologies: Innovation in higher education in Romania. In The International Scientific Conference eLearning and Software for Education; Bucharest. Bucharest: "Carol I" National Defence University, Vol. 1, pp. 400-406.

Webster, C. A., Stodden, D. F., Carson, R. L., Egan, C., \& Nesbitt, D. (2016). Integrative public health-aligned physical education and implications for the professional preparation of future teachers and teacher educators/researchers in the field. Quest, 68(4), 457-474.

Yang, Y. R. (2018). The innovation of college physical training based on computer virtual reality technology. Journal of Discrete Mathematical Sciences \& Cryptography, 21(6), 1275-1280.

Zhang, F. (2019). The Function of introducing multimedia technology into badminton teaching in colleges and universities. In International conference on computer, communications and mechatronics engineering (CCME 2018). DEStech Transactions on Computer Science and Engineering, Vol. 332, pp. 120-124.

Zheleznyak, Yu. D., Petrov, P. K. (2002). Osnovy nauchno-metodicheskoj deyatel'nosti $\mathrm{v}$ fizicheskoj kul'ture i sporte [Fundamentals of scientific and methodological activities in physical education and sports]: textbook for students of higher educational institutions. M.: Publishing. Center "Academy", 264 p. (in Russian). 